\title{
LACTOGENESIS IN THE RAT: AN ULTRASTRUCTURAL STUDY OF THE INITIATION OF THE SECRETORY PROCESS
}

\author{
R. T. GHATTERTON, JR, J. A. HARRIS AND R. M. WYNN \\ Department of Obstetrics and Gynecology, Abraham Lincoln School of Medicine, \\ University of Illinois at the Medical Center, Chicago, \\ Illinois 60612, U.S.A.
}

(Received 29th October 1974)

\begin{abstract}
Summary. Three specimens were taken from mammary glands of rats killed on the 18th and 21st days of pregnancy and on the 1st day of lactation. Ultrastructural features of the tissue were compared among rats within and between the two stages of development. The similarity among specimens from the same rats made feasible a comparison of serial biopsies obtained every $4 \mathrm{hr}$, starting on the afternoon of the 21 st day of pregnancy. From the 18th to the 21 st days of pregnancy, a marked increase in the amount of rough endoplasmic reticulum occurred. The alveolar cells of rats killed on both days and in biopsies obtained at 17 and $13 \mathrm{hr}$ before parturition contained abundant small lipid droplets and vacuoles containing many protein granules with little clear fluid (stasis vacuoles). Alveolar lumina were distended with secretion by $17 \mathrm{hr}$ before parturition. Between 8 and $12 \mathrm{hr}$ before parturition, the accumulated protein and lipid were rapidly extruded from the alveolar cells despite evidence of continued biosynthesis. It is suggested that active transport processes are initiated independently of milk synthesis before parturition.
\end{abstract}

\section{INTRODUGTION}

During the process of lactogenesis at parturition, the parenchymal cells of rat and mouse mammary glands undergo a rapid transition from a relatively inactive state to a condition whereby the full synthetic capacity is expressed (Wellings, 1969; Arrata \& Chatterton, 1974). Although cell division is a necessary process for differentiation of epithelial cells of mammary glands explanted from virgin mice (Owens, Vonderhaar \& Topper, 1973), it is generally agreed that there is little mitotic activity in pregnant mice and rats during the immediate antepartum period (Griffith \& Turner, 1961; Munford, 1963; Traurig, 1967; Liu \& Davis, 1967). The changes that take place in the epithelial cells at lactogenesis therefore occur in genetically competent cells in which expression of their potential is thought to be prevented largely by the inhibitory effects of progesterone (Shinde, Ôta \& Yokoyama, 1965; Kuhn, 1969a; Turkington \& Hill, 1969; Davis, Wikman-Coffelt \& Eddington, 1972).

Intraductal injections of prolactin in mammary glands of the rabbit have been shown ultrastructurally to induce lactogenesis (Fiddler, Birkinshaw \& 
Falconer, 1971; Tobon, Josimovich \& Salazar, 1972), but neither subcutaneous injections of prolactin (Kuhn, 1969b) nor pharmacological elevation of serum prolactin (Simpson, Simpson \& Kulkarni, 1973) were effective in increasing lactose synthesis in the rat. According to Desclin (1952), a mammary gland response to prolactin may be exhibited in the rat only after the maximal ovarian response to prolactin is exceeded by the dose administered, thus emphasizing the opposing effects of prolactin and progesterone in lactogenesis.

As reviewed by Wellings (1969), many comparisons have been made between the ultrastructure of prelactational and lactational mammary alveolar cells of rats, mice, guinea-pigs, hamsters, and rabbits. Morphometric techniques have been employed by Hollmann (1969) to study changes in subcellular organization in mice: e.g. approximately a $30 \%$ increase in the rough endoplasmic reticulum during the last 3 days of gestation and a similar increase in the Golgi volume within a 6 -hr period spanning the time of parturition. The requirement of adrenocortical hormone for rough endoplasmic reticulum development (Mills \& Topper, 1970) and the suppression of this development in relation to progesterone levels (Miller, Chatterton \& Harris, 1974; Chatterton, King, Ward \& Chien, 1975) have been discussed previously. The formation of secretory products in the mammary glands of rats during pregnancy has been described by Murad (1970).

The purpose of this communication is to describe the activation of transport processes by which the accumulated secretory products are completely extruded from the alveolar cells within 8 to $12 \mathrm{hr}$ before parturition. Since large quantities of secretory products accumulate within the epithelial cells before, but not after, initiation of the transport process, this process appears to be promoted independently of hormonal activation of milk synthesis.

\section{MATERIALS AND METHODS}

Rats from the Holtzman Company, Madison, Wisconsin, were received within the first week after detection of spermatozoa in the vaginal washings, and were maintained in an air-conditioned room illuminated daily from 05.00 to 19.00 hours. Starting at 17.00 hours on the 21st day of pregnancy, $8 \mathrm{~mm}^{3}$ biopsy specimens of mammary glands were taken every $4 \mathrm{hr}$ under ether anaesthesia until the time of parturition on the 22nd day. The duration of anaesthesia for each biopsy was approximately $2 \mathrm{~min}$. Not more than five biopsies were taken from any one rat. The time at which each biopsy specimen was taken was calculated from the time the first offspring was born.

Tissue was removed with iridectomy scissors and placed immediately in $1 \%$ osmium tetroxide and $2.5 \%$ glutaraldehyde in $0.1 \mathrm{~m}$-phosphate buffer, $\mathrm{pH} 7.4$, osmolality 600 to $700 \mathrm{mosmol} / \mathrm{kg}$, at $4^{\circ} \mathrm{G}$. The tissue was cut into pieces, approximately $0.12 \mathrm{~mm}^{3}$, and fixation was continued for 1 or $2 \mathrm{hr}$. After rinsing in $0.1 \mathrm{M}$-phosphate buffer, $\mathrm{pH} 7.4$, brought to a similar osmolality with sucrose, the tissue was stained with $1 \%$ aqueous uranyl acetate at room temperature for $20 \mathrm{~min}$.

The skin incision was not large enough to require suturing. Previous work had shown that the stage of mammary gland development observed in a given 


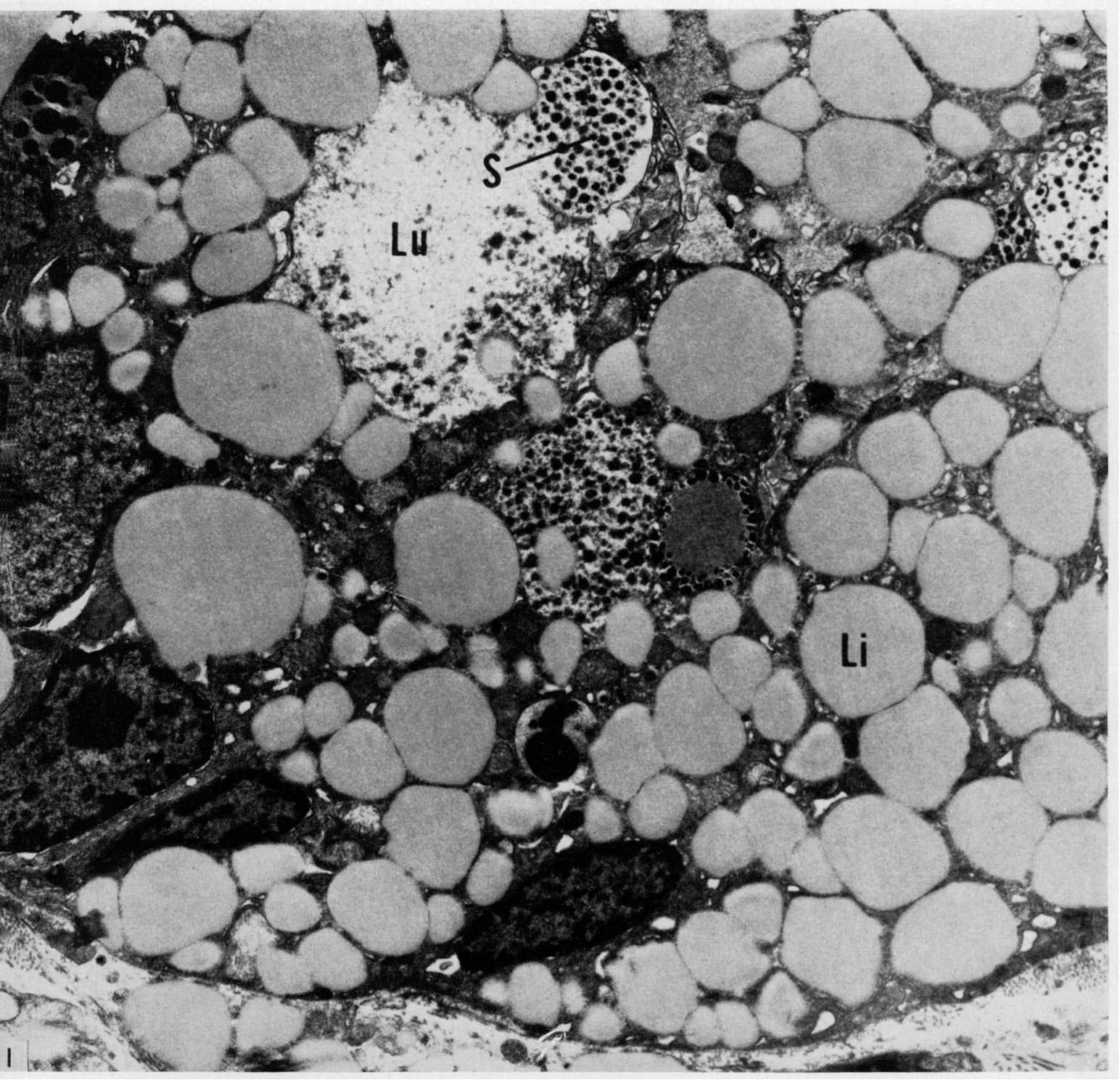

Fic. 1. Mammary gland alveolar cells from a rat $17 \mathrm{hr} 5 \mathrm{~min}$ before parturition. The lumen (Lu) contains little lipid and a small number of protein granules. The parenchymal cells contain abundant lipid droplets ( $\mathrm{L}, \mathrm{i})$ and stasis vacuoles containing protein granules. One stasis vacuole $(S)$ is being extruded into the alveolar lumen. $\times 6250$. 
PLATE 2

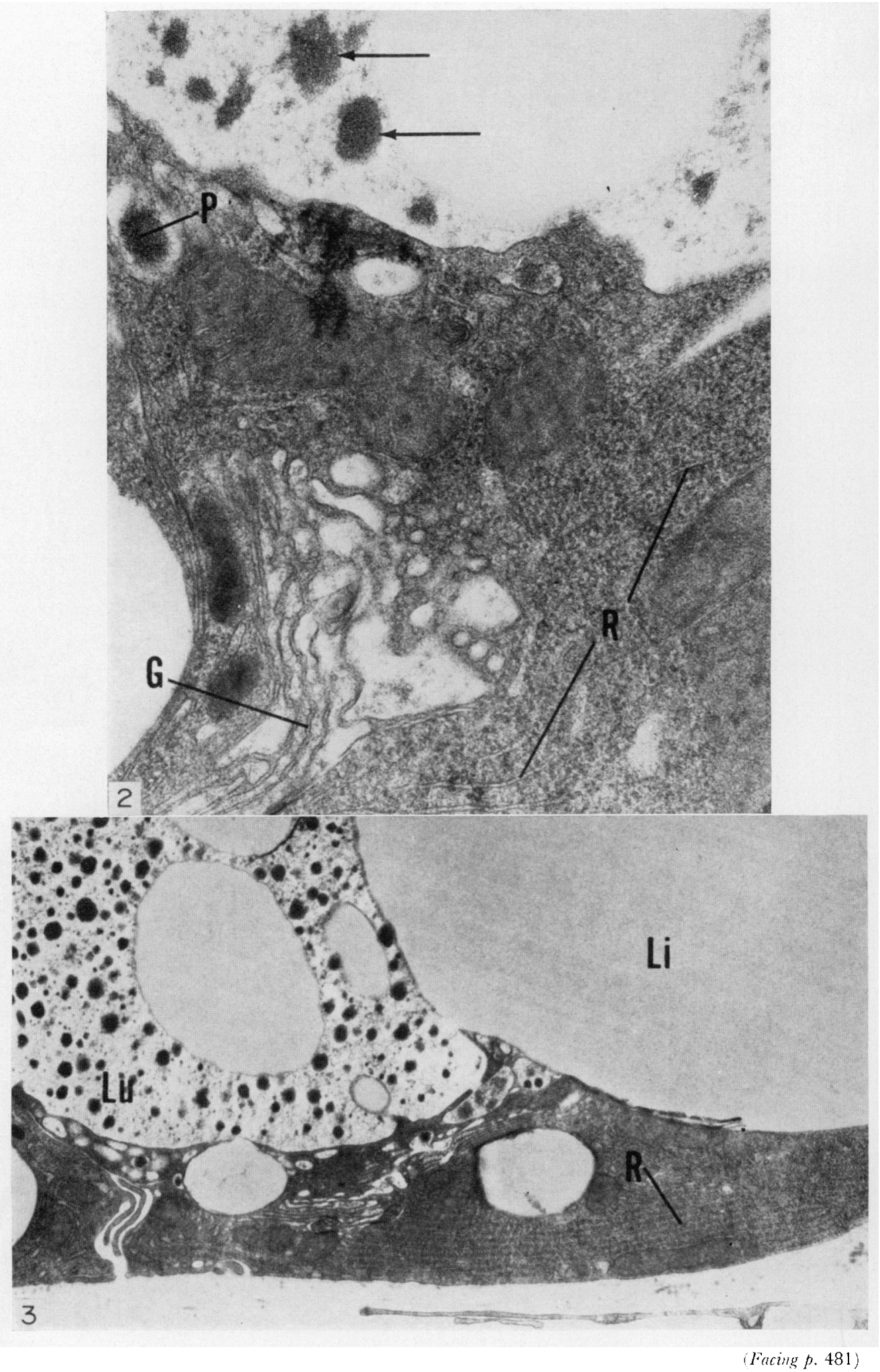


rat was similar, regardless of the gland or the part of the gland subjected to biopsy at any one time. Specimens were removed near the periphery of the glands; and successive biopsies were obtained from areas in which the blood supply had not been interrupted. Rats not involved in the serial biopsy procedures were used as donors of mammary tissue at 18 and 21 days of pregnancy and on the 1st day of lactation. Tissues from lactating rats were fixed in $3.35 \%$ glutaraldehyde in $0 \cdot 1 \mathrm{M}$-phosphate buffer, $\mathrm{pH} 7 \cdot 6$, osmolality $700 \mathrm{mosmol} / \mathrm{kg}$ for $1 \frac{1}{\mathrm{hr}}$ at room temperature. After rinsing in buffer brought to a similar osmolality with sucrose, the tissues were postfixed for $1 \mathrm{hr}$ in $1 \%$ osmium tetroxide.

All fixed tissues were dehydrated through a series of ascending concentrations of ethanol, transferred to propylene oxide, and embedded in Araldite. Thick $(2 \mu \mathrm{m})$ sections were prepared on a Porter-Blum MT-1 ultramicrotome for phase-contrast microscopy. A minimum of 200 representative thin $(600 \AA)$ sections from areas of blocks selected by phase-contrast microscopy were prepared from each biopsy specimen. The thin sections were stained with lead citrate and examined with a Zeiss EM-9A electron microscope.

\section{RESULTS}

All rats littered on the 22nd day after spermatozoa were detected in vaginal washings, counting Day 1 as the last day of oestrus. Nursing and maternal behaviour were not apparently affected by the biopsy procedure. The ultrastructure of mammary glands removed from rats killed at 14.00 hours on the 18 th and 21 st days of pregnancy was similar to that of the first biopsy sample (Pl. 1, Fig. 1) obtained at $17 \mathrm{hr} 5 \mathrm{~min}$ before parturition (Day 21) with respect to intracellular lipid and protein. The volume of luminal fluid and the formation of rough endoplasmic reticulum increased perceptibly from Day 18 to Day 21. The specimen shown in Pl. 1, Fig. 1 exhibits somewhat less rough endoplasmic reticulum than is typical for this time before parturition but is otherwise representative. Numerous small lipid droplets and vacuoles containing many protein granules with little clear fluid (stasis vacuoles) were present in the epithelial cells. At $12 \mathrm{hr} 55 \mathrm{~min}$ before birth, many parenchymal cells were still relatively inactive. Plate 2, Fig. 2 shows the abundance of free ribosomes that have not yet become membrane-bound in one such cell. Golgi membranes were extensive but they contained few protein granules at this time.

In subsequent serial biopsies from three rats, an increase in the rough endoplasmic reticulum formation from existing free ribosomes was noted, but

\section{EXPLANATION OF PLATE 2}

Fig. 2. Apex of rat mammary parenchymal cell at $12 \mathrm{hr} 55$ min before parturition, showing extensive Golgi membranes $(G)$ with little accumulation of protein. One Golgi vesicle containing a protein granule $(P)$ is seen near the apical membrane and several protein granules (arrows) are present in the luminal fluid. The dense granularity of the cytoplasm is caused by the numerous ribosomes unassociated with the developing reticular membranes $(R) . \times 45,000$.

Fig. 3. Alveolar cell at $8 \mathrm{hr} 50 \mathrm{~min}$, showing a greatly expanded lumen (Lu) and flattened cells from which stasis vacuoles have been extruded and in which lipid droplets have coalesced and been released in the form of large droplets $(\mathrm{Li})$. Numerous parallel sacs of rough endoplasmic reticulum $(R)$ are found in addition to abundant free ribosomes. $\times 13,050$. 
the most significant finding during the remaining antepartum period was the extrusion of the accumulated lipid and protein from the alveolar cells. By $8 \mathrm{hr}$ 50 min before birth (Pl. 2, Fig. 3) most of the lipid and all of the stasis vacuoles had been extruded from the alveolar cells, leaving them flattened. Most cells contained abundant rough endoplasmic reticulum and Golgi vacuoles appeared with one to three protein granules in a large volume of clear fluid. Lipid droplets had coalesced and had been or were being extruded from the cell, resulting in the appearance of many lipid droplets in the luminal fluid. The appearance of the cells remained unchanged at $4 \mathrm{hr} 25 \mathrm{~min}$ and at $1 \mathrm{hr}(\mathrm{Pl} .3$, Fig. 4). Biopsies obtained from the mammary glands of rats during the 1st day post partum revealed similar ultrastructural features with an even more extensive rough endoplasmic reticulum and a more expanded luminal volume (Pl. 3, Fig. 5).

\section{DISCUSSION}

It is evident that, once the transport processes had begun between 8 and $12 \mathrm{hr}$ before parturition, the products of milk synthesis were rapidly extruded from the alveolar cells against a concentration gradient, whereas before activation of these processes the majority of the synthesized products remained within the cells. The rough endoplasmic reticulum developed from existing free ribosomes over a 3-day period, but the rate of development was accelerated during the last $12 \mathrm{hr}$ of gestation.

Studies of rats and mice have shown that the increase in the RER that occurs during the last 3 days of gestation (Hollmann, 1969) is a necessary process for the synthesis of milk constituents (Denamur, 1969). This rough endoplasmic reticulum formation is not dependent upon new rough endoplasmic reticulum synthesis, but represents redistribution of free ribosomes to the membranebound state in the presence of adrenocorticosteroids (Mills \& Topper, 1970; Oka \& Topper, 1971). The formation of the rough endoplasmic reticulum, however, is not sufficient for assembly of the synthetic systems for milk production. Prolactin induces new RNA synthesis (Liu \& Davies, 1967) necessary for translation of casein (Oka \& Topper, 1971) and probably also for synthesis of lipid (Popjak, Folley \& French, 1949; Stein \& Stein, 1967).

The assembly of the rough endoplasmic reticulum in the presence of elevated blood levels of corticosterone and prolactin appears to be inhibited in the presence of high levels of progesterone (Miller et al., 1974), and the rate of formation of the rough endoplasmic reticulum during the last 3 days of pregnancy parallels

\section{EXPLANATION OF PLATE 3}

Fig. 4. Rat mammary gland alveolar cell at $1 \mathrm{hr}$ before parturition. The ultrastructure is similar to that seen at $8 \mathrm{hr} 50 \mathrm{~min}$ and at $4 \mathrm{hr}$, except that almost all of the large lipid droplets $(\mathrm{Li})$ have been extruded into the lumen $(\mathrm{Lu})$. The rough endoplasmic reticulum $(R)$ is more distinct. Vesicles contain only single protein granules $(P) . \times 17,500$.

FIG. 5. Alveolar cell approximately $6 \mathrm{hr}$ post partum. Lumen (Lu), lipid (Li), and endoplasmic reticulum (R) are seen. The cell appears similar to those observed as early as $8 \mathrm{hr} 50 \mathrm{~min}$ before parturition except that free ribosomes are found in smaller numbers. $\times 15,000$. 

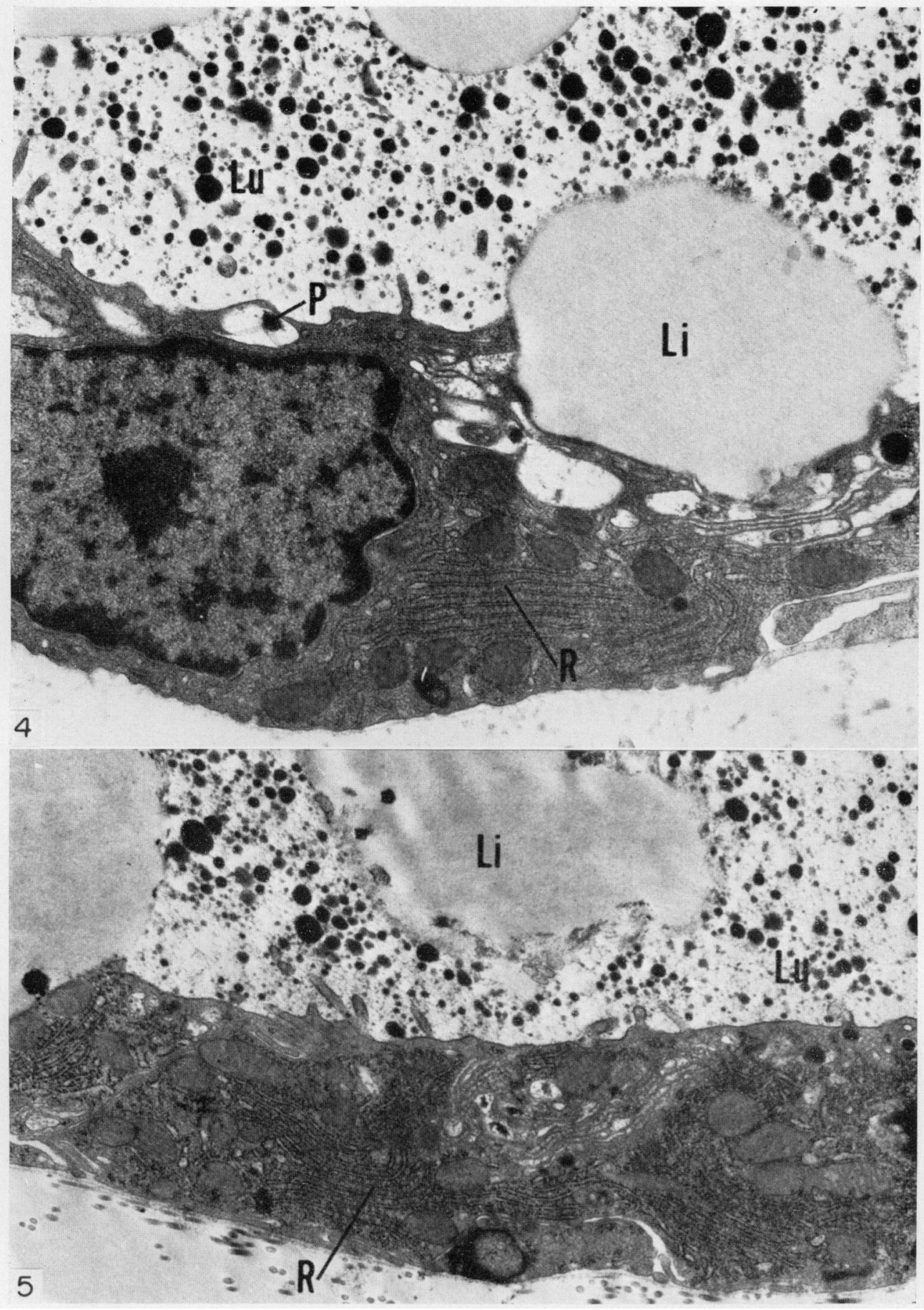
the declining levels of serum and tissue progesterone (Chatterton et al., 1975). Furthermore, Turkington \& Hill (1969) have shown that formation of $\alpha$ lactalbumin, a necessary component for the synthesis of lactose, is inhibited by progesterone, and the lactose content of the mammary glands does not increase until the last day of gestation (Shinde et al., 1965). The present study confirms earlier observations of the formation of the rough endoplasmic reticulum during the last 3 days of gestation and, particularly, the more rapid rate of formation during the last night before parturition. The rapid rise in the capacity for synthesis of casein, lipid and lactose that occurs on the last day of pregnancy was also associated with accumulation of lipid and protein within the alveolar cells at more than $12 \mathrm{hr}$ before parturition. This finding was similar to that observed by Mills \& Topper (1970) in mammary gland explants cultured in the presence of insulin, cortisol and prolactin. Because of the presence of abundant lipid droplets and stasis vacuoles, however, these cells more closely resemble those present in the early stages of involution (Richards \& Benson, 1971) than actively secreting mammary cells. This result may be expected since the cells on the last day of gestation have almost the synthetic capacity of the actively secreting tissue, but the products of secretion have not been removed. Within 8 to $12 \mathrm{hr}$ before parturition, a transport process is initiated whereby the parenchymal cells are almost completely cleared of secretory products though no secretions have been withdrawn from the alveolar lumina. Extrusion of lipid and release of protein secretions from the alveolar cells are thus independent of the synthetic capacity of the cells or concentration gradients. An active transport process is required to explain these observations. Induction of active transport cannot be a result of the accumulation of sufficient secretory products within the alveolar cells because, once the process is begun, the cells do not accumulate significant amounts of secretory products again until involution of the gland is brought about at weaning. Nevertheless, a similar condition after weaning suggests that continued stimulation is necessary to maintain active transport. In this respect, it is interesting that explanted glands exposed to insulin, cortisol, and prolactin accumulated secretory products within the alveolar cells. Although some secretory products were observed in the alveolar lumina, as in the case of mammary tissue removed from rats more than $12 \mathrm{hr}$ before parturition, clearance of the products from the cells as observed $8 \mathrm{hr}$ before parturition did not occur (Mills \& Topper, 1970).

The stimulus for initiating active transport is probably not withdrawal of progesterone because the onset is not correlated with the gradual decline in progesterone over the last few days of gestation (Wiest, 1970; Chatterton et al., 1974). Although withdrawal of progesterone should not be excluded as a factor, other changes that occur at parturition, such as a rise in plasma prostaglandin (Labhsetwar \& Watson, 1974) and oxytocin, must be considered as possible inducers of the transport process.

\section{AGKNOWLEDGMENT}

This investigation was supported by NIH research grant number HD-06419 from the Division of Child Health and Human Development. 


\section{REFERENCES}

Arrata, W. S. M. \& Chatterton, R. T. (1974) Human lactation: appropriate and inappropriate. In Obstetrics and Gynecology Annual, pp. 443-472. Ed. R. M. Wynn. Appleton-Century-Crofts, New York.

Chatterton, R. T., JR, King, W. J., Ward, D. A. \& Chien, J. L. (1975) Differential responses of prelactating and lactating mammary gland to similar tissue concentrations of progesterone. Endocrinology, 96, 903-910.

Davis, J. W., Wikman-Coffelt, J. \& Eddington, C. L. (1972) The effect of progesterone on biosynthetic pathways in mammary tissue. Endocrinology, 91, 1011-1019.

Denamur, R. (1969) Changes in the ribonucleic acids of mammary cells at lactogenesis. In Lactogenesis: the Initiation of Milk Secretion at Parturition, pp. 53-64. Eds. M. Reynolds and S. J. Folley. University of Pennsylvania Press, Philadelphia.

Desclin, L. (1952) Recherches sur le déterminisme des phénomènes de sécrétion dans la glande mammaire du rat. Annls Endocr. 13, 120-136.

Fiddler, T. J., Birkinshaw, M. \& FatconeR, I. R. (1971) Effects of intraductal prolactin on some aspects of the ultrastructure and biochemistry of mammary tissue in the pseudopregnant rabbit. 7. Endocr. 49, 459-469.

GRIFFITH, D. R. \& TURNER, C. W. (1961) Normal growth of rat mammary glands during pregnancy and early lactation. Proc. Soc. exp. Biol. Med. 106, 448-450.

Hollmann, K. H. (1969) Quantitative electron microscopy of subcellular organization in mammary cells before and after parturition. In Lactogenesis: The Initiation of Milk Secretion at Parturition, pp. 27-41. Eds. M. Reynolds and S. J. Folley. University of Pennsylvania Press, Philadelphia.

Kunn, N. J. (1969a) Specificity of progesterone inhibition of lactogenesis. F. Endocr. 45, 615-616.

Kunn, N. J. (1969b) Progesterone withdrawal as the lactogenic trigger in the rat. F. Endocr. 44, 39-54.

Labhsetwar, A. P. \& Watson, D. J. (1974) Temporal relationship between secretory patterns of gonadotropins, estrogens, progestins, and prostaglandin-F in periparturient rats. Biol. Reprod. 10, 103-110.

LIU, T. M. Y. \& Davis, J. W. (1967) Induction of lactation by ovariectomy of pregnant rats. Endocrinology, 80, 1043-1050.

Miller, T. T., Chatterton, R. T., Jr \& Harris, J. A. (1974) Ultrastructure of the rat mammary gland after lactogenesis induced by perphenazine. F. Reprod. Fert. 40, 143-149.

Mirts, E. S. \& Topper, Y. J. (1970) Some structural effects of insulin, hydrocortisone, and prolactin on mammary gland explants. F. Cell Biol. 44, 310-328.

MUNFORD, R. E. (1963) Changes in the mammary glands of rats and mice during pregnancy, lactation and involution. 7. Endocr. 28, 17-34.

MuRAD, T. M. (1970) Ultrastructural study of rat mammary gland during pregnancy. Anat. Rec. 167, $17-35$.

OKA, T. \& TOPPER, Y.J. (1971) Hormone-dependent accumulation of rough endoplasmic reticulum in mouse mammary epithelium cells in vitro. 7. biol. Chem. 246, 7701-7707.

OWENs, I. S., VonderhaAR, B. K. \& TOPPER, Y. J. (1973) Concerning the necessary coupling of development to the proliferation of mammary epithelial cells. F. biol. Chem. 248, 472-477.

Popjak, G., Folley, S. J. \& French, T. H. (1949) Synthesis of the short-chain fatty acids of milk fat from acetate. Archs Biochem. 23, 508-510.

Richards, R. G. \& Benson, G. K. (1971) Ultrastructural changes accompanying involution of the mammary gland in the albino rat. F. Endocr. 51, 127-135.

Shinde, Y., ÔTA, K. \& Yoxoyama, A. (1965) Lactose content of mammary glands of pregnant rats near term: effect of removal of ovary, placenta, and foetus. F. Endocr. 31, 105-114.

Simpson, A. A., Simpson, M. H. W. \& Kulkarni, P. N. (1973) Effect of perphenazine during late pregnancy on prolactin production and lactogenesis in the rat. 7. Endocr. 57, 431-436.

Stein, O. \& Stein, Y. (1967) Lipid synthesis, intracellular transport, and secretion. II. Electron microscopic autoradiographic study of the mouse mammary gland. F. Cell Biol. 34, 251-263.

Tobon, H., Josimovich, J. B. \& Salazar, H. (1972) The ultrastructure of the mammary gland during prolactin-induced lactogenesis in the rabbit. Endocrinology, 90, 1569-1577.

TrauRIG, H. H. (1967) A radiographic study of cell proliferation in the mammary gland of the pregnant mouse. Anat. Rec. 159, 239-248.

TURKIngton, R. W. \& HiLL, R. L. (1969) Lactose synthetase: progesterone inhibition of the induction of $\alpha$-lactalbumin. Science, N.Y. 163, 1458-1459.

WELLINGs, S. R. (1969) Ultrastructural basis of lactogenesis. In Lactogenesis: The Initiation of Milk Secretion at Parturition, pp. 5-25. Eds. M. Reynolds and S. J. Folley. University of Pennsylvania Press, Philadelphia.

WIEST, W. G. (1970) Progesterone and 20 $\alpha$-hydroxypregn-4-en-3-one in plasma, ovaries and uteri during pregnancy in the rat. Endocrinology, 87, 43-47. 